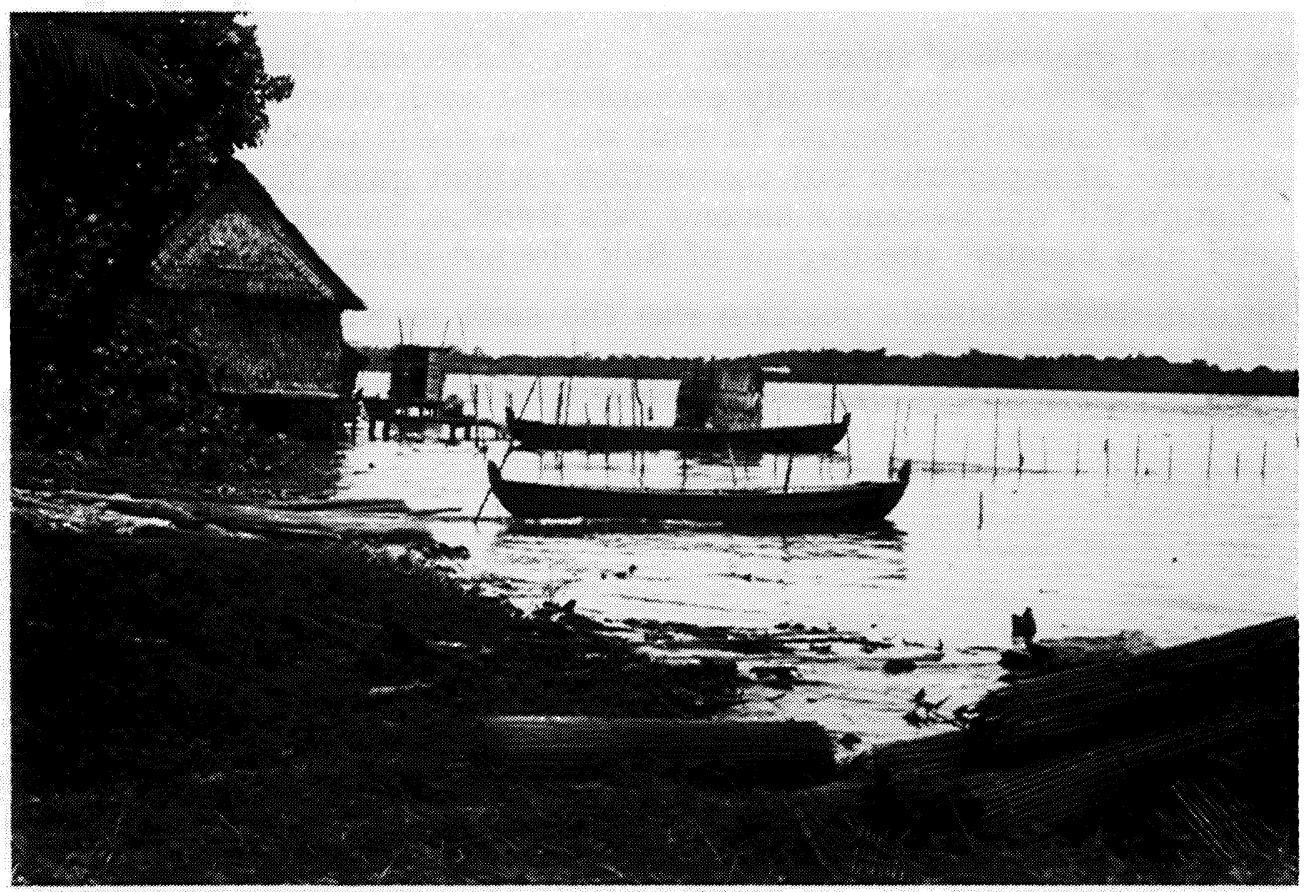

PLATE 1: Pulau Kompei with Pulau Sembilan in the background. Between them lies the northern entrance to Aru Bay.

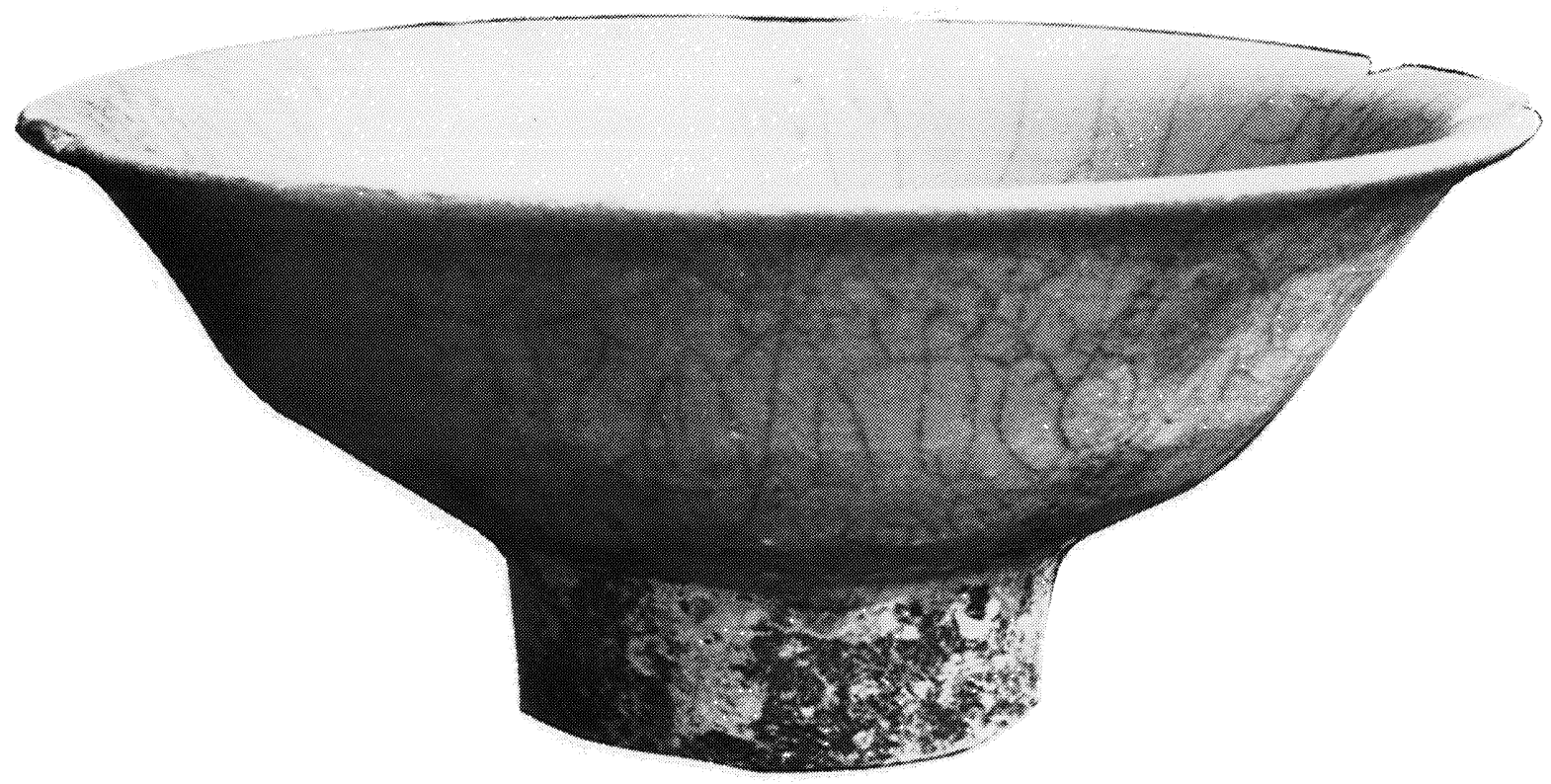

PLATE 2: Pulau Kompei Stoneware Bowl (See Appendix 1, Fig. 2D) 


\section{A NOTE ON PULAU KOMPEI IN ARU BAY, NORTHEASTERN SUMATRA*}

\section{E. Edwards McKinnon and Tengku Luckman Sinar}

The story of Pulau Kompei is intimately linked with that of Aru Bay and its immediate hinterland, an area drained by several sizeable rivers, the most important of which is the Besitang, ${ }^{1}$ rising on the slopes of Gunung Mesigit on the eastern side of the Bukit Barisan range. We first visited the site on August 17, 1974, prompted by a reference to "Kompei" by $O$. W. Wolters ${ }^{2}$ and the reprinting of John Anderson's Mission to the East Coast of Sumatra, in which Kompei is referred to as Pulau Sampah tua. ${ }^{3}$ We immediately encountered significant traces of former habitation in the form of sampah tua, or ancient rubbish of the nineteenth century Malays. Although we carried out no excavations at Pulau Kompei, we did make surface collections of potsherds and other artifacts which have enabled us to give a tentative dating to at least one period of trading activity there. We were able to visit the site on three subsequent occasions up to early 1977 , and our further investigations led us to believe that we had rediscovered the "Kompei" mentioned in Chinese records. We acknowledge, however, that an inconsistency seems to exist between the suggested location of the toponym and at least one of the products said to be available there. The following note is a summary of our investigations between 1974 and 1977 .

\section{Pulau Kompei and Aru Bay}

The island of Pulau Kompei and a village of the same name are situated at the northern side of the northern entrance to Aru Bay (Telok Aru), $4^{\circ} 12^{\prime} \mathrm{N} .98^{\circ}$ $15^{\prime} \mathrm{E} .{ }^{4}$ Located on a narrow channel which separates it from the rocky northern shore of Pulau Sembilan, Pulau Kompei is ideally situated to control the entrance

* The authors would like to thank Professor $\mathrm{O}$. W. Wolters for reading an earlier draft of this paper and making several helpful suggestions.

1. J. A. van Rijn van Alkemade, "Een Bezoek aan de Aroe-baai," Bijdragen tot de Taal-, Land-en Volkenkunde, 38 (1889), pp. 55-73. He states that the name derives from besi melintang, a sandbar resembling the blade of a knife which lay diagonally across the mouth of the river. Before reaching Aru Bay the Besitang is joined by the Tungkam, Halaban, Sikundur, and Sisirah at Tanjong Keramat, and in the bay itself by the Salahaji.

2. See his The Fall of Srivijaya in Malay History (Kuala Lumpur: Oxford University Press, 1970), p. 42.

3. John Anderson, Mission to the East Coast of Sumatra (1826; reprint ed. Kuala Lumpur: Oxford in Asia, 1971), p. 239.

4. The exact location is given in: Gazeteer No. 10. Sumatra (Washington: United States Navy Department, Hydrographic Office, 1944). 


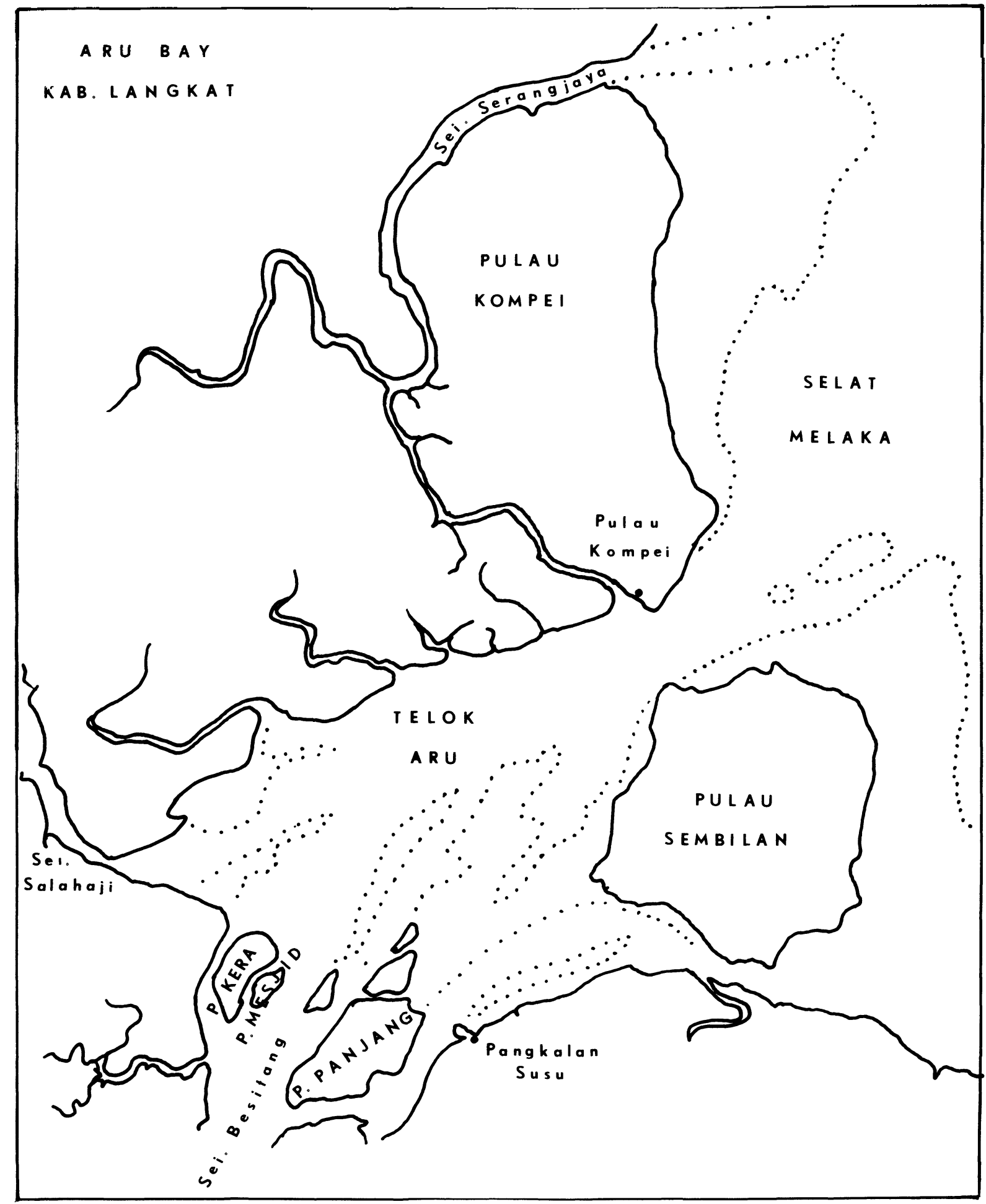

MAP 1 
to the bay. ${ }^{5}$ (See Map 1.) To the north and west of the island runs the Sungei (river) Serangjaya, ${ }^{6}$ and a narrow channel through mangrove swamps connects this river with Aru Bay and the Sungei Besitang in the southwest. Although there are low hills around the bay, much of the land in the interior is flat and swampy. A short distance to the south lies the modern oil port of Pangkalan Susu, $\mathrm{Kab}$. Langkat, and due east the open waters of the Selat Melaka and the coast of Perak.

The name Kompei or Kampei, also variously spelled as Kompe, Kumpai, or Kum+1 peh, seems to be derived from the Malay word kumpai, or rumput kumpai, a rush (Panicum myrnus), the pith of which can be used as a wick and the young shoot of which is edible. ${ }^{7}$ It is not uncommon in the Indonesian archipelago for the names of plants to be given to places. Examples are found elsewhere in Sumatra and the area of the Selat Melaka, one of the most famous being Penang, or Pulau Pinang, which takes its name from the Pinang palm. ${ }^{8}$ Kompei is probably yet another example of such usage.

Little is known of the history of the area until fairly recent times. A few prehistoric implements have been found in the environs of Aru Bay, and shell middens once existed at Seruwai and Sungei Hui on the north bank of the Tamiang river a short distance to the north of the bay. 9 Although in 1924 a site known as Kota Batu was reportedly discovered by a forestry official in the jungle on the middle reaches of the Besitang river, ${ }^{10}$ apparently no archaeologist visited it. Local inhabitants have suggested verbally that there were other fortified sites in the region, but their existence has not been confirmed. Dutch sources connect Aru Bay with an erstwhile Batak polity of Aru or Haru, which the present authors believe had its center in the Deli region ${ }^{11}$ although its power may once have extended as

5. The southern entrance was formerly obstructed by a sandbar.

6. See "Aanvullingsnota van toelichting betreffende het rijk van Langkat," Tijdschrift van het Bataviaasch Genootschap (hereafter $T B G$ ), 53 (1911), p. 331, where this is described as the "Sungei or terusan" Serangjaya, a name possibly indicating that the channel had been subject to canalization or other hydraulic work at some former time.

7. R. J. Wilkinson, A Malay-English Dictionary (London: Macmillan, 1959), $\mathrm{p}$. 624. See also L. H. Burkhill, A Dictionary of the Economic Products of the Malay Peninsula (Kuala Lumpur: Ministry of Agriculture, 1966), p. 1234. Burkhill gives the botanical name as Hymenachne myurus. Beauv.

8. There are many examples of such usage. Telok Aru, for example, derives from the name of the Casuarina tree, pohon Aru or Rhu, thus: "the bay of Casuarinas."

9. L. C. Heyting, "Memorie van Overgave van der Controleur te Pangkalan Brandan 21 April 1927-1 Juni 1928." Two artifacts were reportedly found in an area of young rubber at Buluh Telang (HM 142 along the BPM pipeline) in October 1927. On shell middens on this coast, see H. R. van Heekeren, The Stone Age of Indonesia (The Hague: Nijhoff, 1972), pp. 86-92. For a more recent discussion of Hoabinhian influence in northeastern Sumatra, see John N. Miksic, "Archaeology, Trade and Society in Northeast Sumatra" (Ph.D. dissertation, Cornell University, 1979).

10. See note by P. C. van Stein Callenfels, in Oudheidkundig Verslag (hereafter OV) (1924), pp. 108-10. Kota Batu is described as situated on the Sungei Pinang, a tributary of the Sungei Besitang above Bengkil.

11. For a discussion of the history of Aru, see A. C. Milner, E. Edwards McKin- 
far as Aru Bay. In the sixteenth and seventeenth centuries and passibly earlier still, the whole area from Langkat south to the Panei/Barumun estuary was known as the Aru coast. ${ }^{12}$

One version of the legend of Puteri Hijau, the Green Princess who fought valiantly against Aceh in the sixteenth century, is associated with Aru Bay and with the river Sijanda [the "widow"] and Pulau Mesjid in particular. Tradition has it that a mosque once stood on Pulau Mesjid, which would explain the name "mosque island," but no trace of the building remains. ${ }^{13}$

Like the Deli area, Aru Bay came under the hegemony of Aceh in the early sixteenth century and remained so until conquered by Siak some time between 1795 and $1811 .^{14}$ In the nineteenth century it was part of the Sultanate of Langkat and administered as the luhak Telok Haru, comprising the five subdistricts of Pulau Kompei, Besitang, Lepan, Babalan, and Pulau Sembilan. ${ }^{15}$

In earlier times it is possible that Pulau Kompei was more of an island than it is today. The encroachment of mangrove (Rhizophora spp.) and the continued silting up of Aru Bay, as has occurred in other parts of the east coast of Sumatra over past centuries, may have done much to alter the general topography of the area, ${ }^{16}$ although silting is unlikely to have had much effect on the importance of Kompei itself.

The main modern navigational approach to Pangkalan Susu through Aru Bay is by means of the southern channel between Pulau Sembilan and the mainland. ${ }^{17}$ This route appears to be a recent development, for in the nineteenth century such an

non, and Tengku Luckman Sinar, "A Note on Aru and Kota Cina," Indonesia, 26 (October 1978), pp. 1-42.

12. Ibid., p. 19.

13. See van Alkemade, "Bezoek," p. 62, where he states that he sought in vain for any remains which would prove or disprove the claims of the Malays regarding the site of the former mosque. The 1:50,000 scale map, SUMATRA. Gouvt. Oostkust van Sumatra, Sheet 2c. (1922), shows a settlement on the southeastern side of Pulau Mesjid. When we visited Pulau Mesjid in 1974, the only signs of habitation were a number of tall coconut palms among the dense undergrowth.

14. W. H. M. Schader, Geschiedenis van Sumatra's Oostkust (Medan: Instituut van Sumatra's Oostkust, 1918), Pt. 2 .

15. See "Aanvullingsnota," pp. 325-53. Luhak = district.

16. For discussions relating to coastal change in this region, see $H . D . T j i a, S$. Asikin, and R. S. Atmadja, "Coastal Accretion in Western Indonesia," Bulletin of the National Institute of Ceology and Mining [Bandung], 1, 1 (1968), pp. 15-45. With regard to South Sumatra, see M. J. G. Chambers and Abdul S. A. Sobur, Problems in Assessing the Rates and Processes of Coastal Changes in the Province of South Sumatra (Bogor: Institut Pertanian Bogor, Pusat Studi Pengelolaan Sumberdaya dan Lingkungan, 1977). See also John N. Miksic, "Archaeology and Palaeogeography in the Straits of Malacca," in Economic Exchange and Social Interaction in Southeast Asia, ed. Karl L. Hutterer (Ann Arbor: Michigan Papers on South and Southeast Asia No. 13, 1977), pp. 155-75.

17. For a description of the present-day approach to Aru Bay and Pangkalan Susu, see The Malacca Strait Pilot, 4th ed. (London: Admiralty Hydrographic Office, 1958), p. 77. 
approach was said to be obstructed by a sandbar. ${ }^{18}$ As a result of dredging, quite large ships may now enter the bay by means of its southern entrance.

Small sailing vessels of relatively shallow draft still make use of the northern channel between Pulau Kompei and the northern shore of Pulau Sembilan. ${ }^{19}$ The leeward side of the Kompei headland affords an immediate and excellent protected anchorage for small vessels entering the bay by the northern channel from the waters of the Selat Melaka.

The modern village of Pulau Kompei consists of a variety of houses on stilts along the water's edge and other simple houses built directly on the sand. It stands on a raised spit of sand separated from the "mainland" of the island by a narrow, muddy, and densely vegetated tidal creek. Behind the village rises a hill known as Bukit Jantan, the summit of which is occupied by a Chinese cemetery with graves dating from the nineteenth century. The ruins of a small Chinese shrine, or kelenteng, are obscured by undergrowth on the steep landward side of the creek. The population consists mainly of Malays, with a few poor Chinese and a number of Bataks (mostly from Tapanuli) who have settled there in recent years. The inhabitants make their living from fishing, the sale of copra, and the produce of their ladang, including rubber. A short distance upstream from the village, on the channel joining Aru Bay with the Sungei Serangjaya (known as the Terusan), is a charcoal-burning operation.

\section{Ancient Commercial Activity at Pulau Kompei}

\section{Historical References}

The earliest known literary reference to the name Kompei is in the Chinese $H \sin$ T'ang Shu, where a country referred to as Kompe (甘) is recorded as having sent a mission to T'ang China in the year $662 \mathrm{AD}$. The passage records that:

Moreover, there were also three countries, i.e., Ko-lo-she-fen (哥羅舍分), Hsiu-lo-fen (佟踓分), and Kampei (甘果) which paid tribute with their local products. Kampei was on the Nanhai (South China) Sea adjacent to Huan-wang (環王) in the east. Its king, named Chan-t'uo-yueh-mo possessed five thousand excellent soldiers. Ko-lo-she-fen (哥羅舍分) was located on the south of the Nanhai Sea and bordered on To-ho-lo (阷和羅) in the east, while Hsiu-lo-fen 修罪分 lay to the north of the Sea, adjoining Chenla 真腈 in the east. Their customs were roughly the same. They had chiefs and encircled their cities with stockades. There were twenty thousand excellent soldiers in the two countries, while only five thousand in Kampei. ${ }^{20}$

The name appears again in Chau Ju-kua's Chu-fan-chi of 1225 , which gives it the form Chien-pi or Kien-pi (監篦). ${ }^{21}$ Quoting Chou K'u-fei's Ling-wai Tai-ta,

18. Van Alkemade, "Bezoek," p. 57.

19. In 1952, the Kompei channel had a least depth of 10 feet. Malacca Strait Pilot, p. 77 .

20. We are indebted to Professor Liao Shaolian of the Xiamen University, Institute of Southeast Asian Studies, Fujian, for the translation of this passage from the New T'ang History. (Ou-Yang Hsiu, Hsin T'ang Shu, 20 vols. [Peking: Chung Hua Shu Tien, 1975], 20, pp. 1007-72.)

21. Friedrich Hirth and W. W. Rockhill, Chau Ju-kua, His Work on the Chinese and Arab Trade in the Twelfth and Thirteenth Centuries, Entitled Chu fan-chi

(St. Petersburg: Imperial Institute of Sciences, 1911), p. 71. 
Chau Ju-kua notes that "formerly [Kien-pi] was a dependency of San-fo-tsi, but after a fight it set up a king of its own," ${ }^{22}$ a statement which implies that the grip once extended by San-fo-tsi on its former vassels was no longer as strong as it once was. ${ }^{23}$ The name also occurs in the fourteenth century Javanese chronicle, the Nagarakrtagama; ${ }^{24}$ and in the Wu-pei Chih sailing charts (circa 1422), the name Kan-pei ( $甘$ 标) appears. ${ }^{25}$ A further brief reference in the Ying-yai Shenglan of 1433 was probably occasioned by the fact that Cheng-ho, the Muslim eunuch Commander-in-Chief who led seven missions to the Indian ocean in the early fifteenth century, had made a brief stop here during his fourth voyage $(1409-11) .{ }^{26}$

Writing in 1970, Professor Wolters considered that Chien-pi (監篦) may have been the name given by the Sung Chinese to Haru or Tamiang, "toponyms which are in the neighborhood of Kompei island" 27 (see Map 2). The history of Aru or Haru (Deli), Kompei in Aru Bay, and Tamiang, an estuary and anchorage situated immediately to the north of Pulau Kompei, were no doubt intimately interwoven in earlier times, offering, as they did, attractive harbor facilities and commercial possibilities. ${ }^{28}$ In addition to a safe anchorage, all three areas had a good supply of fresh water for shipping.

Both Tamiang and Aru sent envoys to China when ordered to submit by Kubilai Khan in $1292 .{ }^{29}$ Wang Ta Yuan, writing of events on this coast and the Indian Ocean in 1330, mentions Tamiang (淡洋), and notes that Chinese merchants supplied pure gold, iron goods, and coarse bowls to the inhabitants. ${ }^{30}$

Although in the late thirteenth century either Tamiang or Aru may have been the overlord of Kompei, by the fifteenth century Tamiang itself appears to have come under the control of Aru. Writing in 1436, Fei Hsin notes that:

Tamiang is connected with the territory of Aru, and is three days sailing distant from Malacca. It is surrounded everywhere by mountains, and possesses a harbour leading to a large inland stream, surgy and boisterous for a thousand miles, which rushes into the sea. It is pure and fresh and

22. The inference from this statement is that the events had taken place some forty or fifty years before Chau Ju-kua wrote in 1225 .

23. Wolters, Fall, p. 10.

24. Th. G. Th. Pigeaud, Java in the Fourteenth Century, 3 (Leiden: Brill, $1960)$, p. 16.

25. John V. G. Mills, "Malaya in the Wu-Pei-chih Charts," Journal of the Malayan Branch of the Royal A siatic Society [hereafter JMBRAS], 15, 3 (1937), pp. 1-63.

26. John V. G. Mills, Ma Huan. Ying-yai Sheng-lan (Cambridge: Hakluyt Society, 1970), pp. 24, 198.

27. Wolters, Fall, p. 43.

28. These are but three of numerous small harbors on the northeast coast of Sumatra, none of which was any great distance from the others. By the early thirteenth century, the names in the Chinese records begin to be discernible as individual harbors and less as indistinct references to coasts.

29. Wolters, Fall, p. 44.

30. Wang Ta-yuan, Tao-i chih-lueh [A Description of the Barbarian Islands]

(Taiwan: Xuesheng Shu Chu ['赤金鐵器粗碗之屬']，1975)，p.347. (This was originally published about $1350 \mathrm{AD}$.) 




MAP 2 
has a sweet taste. The skippers, who pass there and draw from it, call it the "fresh-water sea" [sic!].

The ground is fertile and the rice abundant. The rice grains are pointed and small, but when cooked very fragrant.

The country yields perfume.

The customs of the people are pretty pure, and the temperature is always hot.

Men and women tuck up their hair into a knot and wear a small cloth around their loins.

Of our wares they use golden, silver and iron wares, earthenwares, and such-like. ${ }^{31}$

Barely a century later, Tomé Pires notes that the Raja of Tamiang, who was a son-in-law of the Raja of Aru, was king of the territory known as Bata. He was much given to piracy. ${ }^{32}$

The kingdom of Bata produces rice, wine and fruits. It also has pitch from which they make many lamps ${ }^{33}$ and they go there for cargoes of them. It also produces a great deal of honey and wax and a little edible camphor. The chief merchandise is canes in large quantities which they call rotaãs (rotan) and these are good merchandise because they serve for cable and threads in every way. 34

Pires also notes that the inhabitants of Tamiang, like other people on this coast in the early sixteenth century, lived in the interior.

Changing circumstances in the coastal regions may in part account for the apparent temporary disappearance of the name Kompei in the late thirteenth century. Analogies from later times suggest that rulers, and consequently the focus of population and trade, tended to move from one location to another, often in order to achieve greater security.

\section{Archaeological Evidence}

In our investigations at Pulau Kompei, surface indications of earlier habitation presented themselves in the form of potsherds, beads, glass, coins, an occasional wafer-like brick similar to those found at Kota Cina in the Deli area, and at least two granite lintels. In one or two places near the Kompei headland there were thick layers of shells of a mollusc known locally as seteng (Placuna spp.), ${ }^{35}$ some

31. George Schlegel, Geographical Notes: The Old States in the Island of Sumatra (Leiden: Brill, 1901), pp. 85-86.

32. Armando Cortesão, ed., The Suma Oriental of Tomé Pires (London: Hakluyt Society, 1944), p. 145 .

33. Both the hinterlands of Aru Bay and the Tamiang river are centers of modern petroleum production.

34. Cortesão, Suma Oriental, p. 146.

35. This is the same name as that mentioned by Wolters as sinting or senteng, the Malay word for two kinds of molluscs, Placuna placenta and Placuna sella in Johore and Riau. See Oliver W. Wolters, "Molluscs and the Historical Geography of Northeastern Sumatra in the Eighth Century A.D.," Indonesia, 22 (October 1976), pp. 9-17. Wilkinson gives sinting or siting, as a thin pearly shell, $P$. sella. See Wilkinson, Malay-English Dictionary, p. 1112. 
of which were partially exposed to view due to natural erosion. Thus the artifacts and natural remains gave a vivid interpretation to the old Malay name of Pulau Sampah tua, the island of ancient rubbish, recorded by Anderson.

Ceramics. During our visits to Pulau Kompei we recovered one complete stoneware bowl (Plate 2, Figure 1D) and ninety-five sherds. The sherds represent vessels of various shapes and sizes but are mainly from small bowls with different colored glazes ranging from white or off-white to ch'ing pai, through gray to shades of green and dark brown. Cross-section drawings and descriptions are given in Appendix 1.

The most striking feature of the potsherds recovered at Pulau Kompei, the bulk of which were identifiable as of Chinese origin, was the total absence of any characteristic green-glazed Lung ch'üan (celadon) ware, which was exported in enormous quantities during the late Sung, Yüan, and early Ming periods of Chinese history. A similar phenomenon was also characteristic of sites in Sarawak, where, of the seven sites excavated by the Harrissons, two were exclusively "Yüeh" and and two exclusively Lung ch'üan. These differences in glaze characteristics are attributable to the different periods in which the various sites were involved in external trade. ${ }^{36}$

Although some Lung ch'üan kilns were already producing green glazed ceramics in the T'ang period (i.e., before the tenth century), the characteristic "celadon" glazes did not appear until the early or middle part of the twelfth century. This suggests that trading activity at Pulau Kompei may have come to an end, at least temporarily, about this time. Obviously Kompei was still known at the time Chau Ju-kua compiled the Chu-fan-chi in AD 1225, but, as Professor Wolters has noted, the Yüan shih, which recorded events on this coast in 1282 , does not mention "Kampe," although the names of both Tamiang, situated immediately to the north, and Aru, to the south, appear. ${ }^{37}$ These inferences are borne out by the Chinese coins found at Pulau Kompei (see Appendix 3 below). The latest of the coins recovered at the site date from the Hsüan-ho reign period of the Hui Tsung emperor, 1119-25 AD.

Few, if any, of the sherds at Kompei seem to relate to those recovered at Kota Cina, which are apparently of later date. It is difficult to compare the Kompei sherds with material published in Chinese reports, because many of the photographs appearing in these are of such poor quality. The published illustrations which approximate most closely to the sherds of Pulau Kompei come from Sarawak, where bowls with incised rings on the interior and also "high-footed" types have appeared in excavated assemblages. These have been dated by Harrisson to about the seventh to tenth centuries. ${ }^{38}$ We are unable to assign a precise dating to the Kompei sherds but would suggest a tentative eleventh to twelfth century date or possibly slightly earlier for most of them. They are utilitarian wares, presumably from provincial kilns in Kwangtung, Fukien, and Chekiang and, with the exception of the ch'ing pai sherd from Paluh Tabuhan (Figure 2c), are of very ordinary quality. This contrasts dramatically with Kota Cina where high quality wares form a significant part of the assemblage. With such a small, and possibly unrepresentative, collection from Pulau Kompei, this comment may, however, need to be revised at a later date.

36. See Carla Zainie and Tom Harrisson, "Early Chinese Stoneware Excavated in Sarawak," Sarawak Museum Journal, 15 (1967), pp. 30-90.

37. Wolters, Fall, p. 44.

38. Zainie and Harrisson, "Chinese Stoneware," p. 85. 


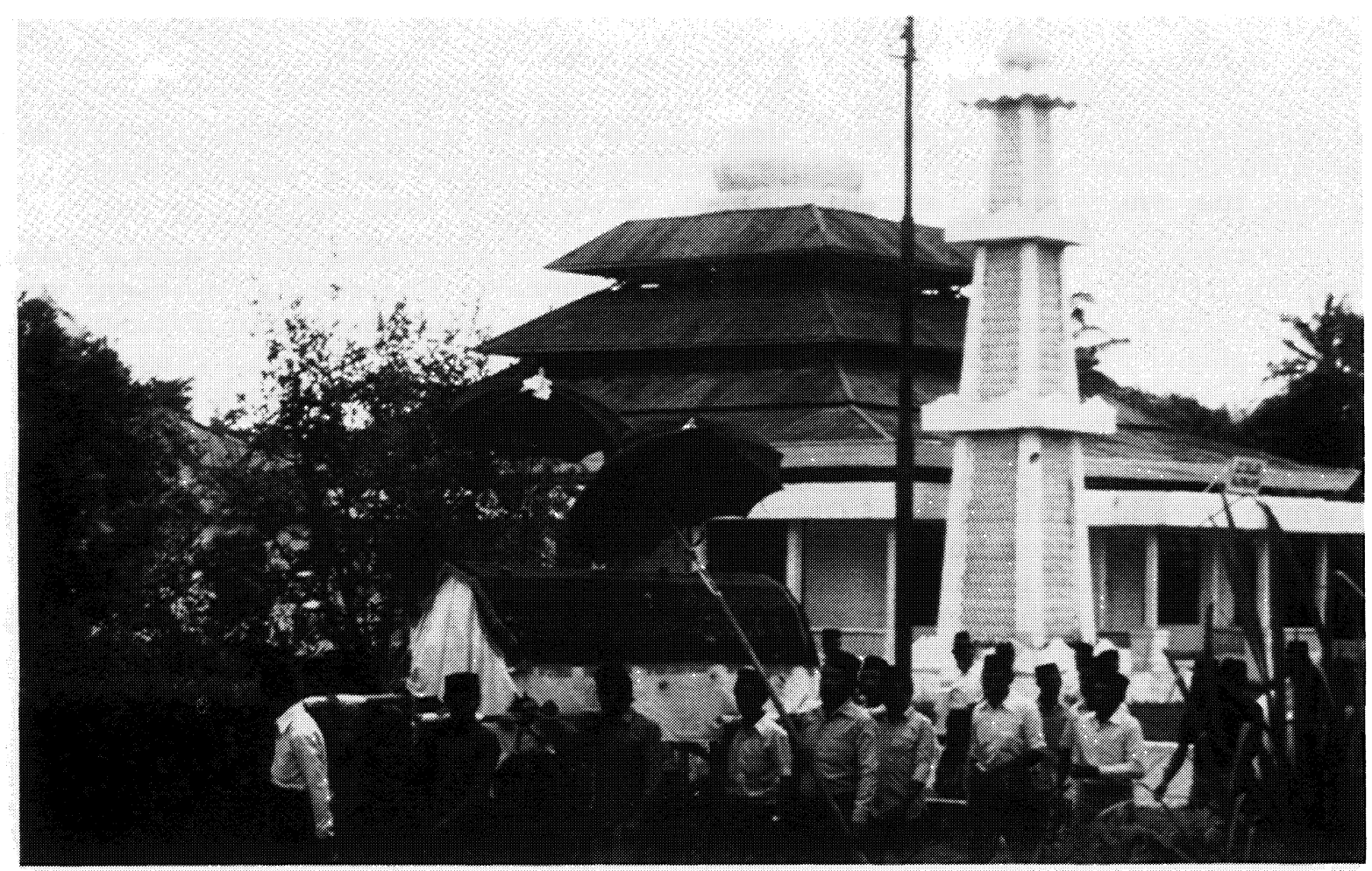

PLATE 3: The school field, Pulau Kompei

Site of recoveries of numerous

beads, coins, and other artifacts

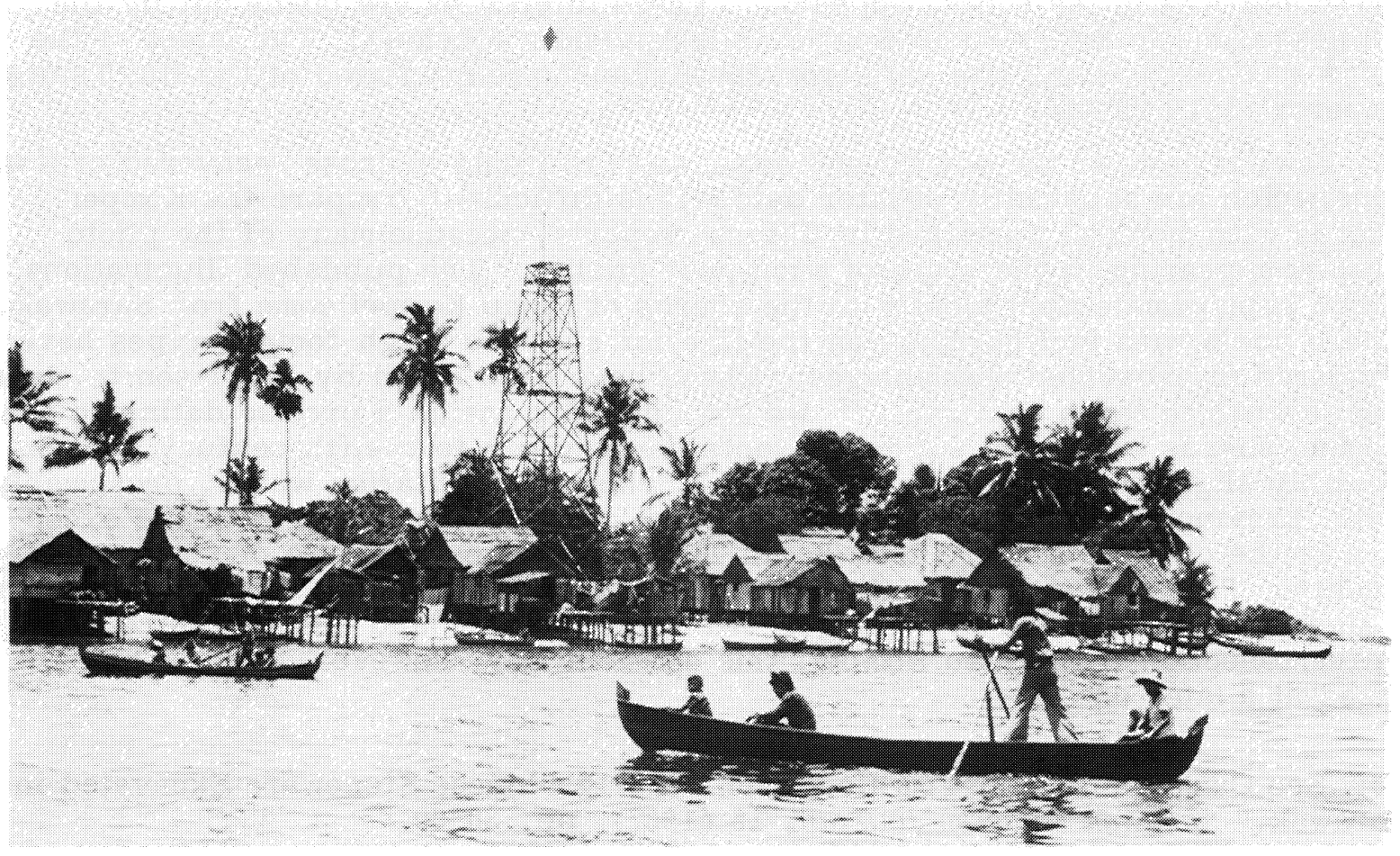

PLATE 4: Pulau Kompei

The tower is a navigational aid for ships leaving Pangkalan Susu on the southern shore of the bay 
Sherds of the Sung period have been found at Paluh Tabuhan to the south of the southern entrance of the bay, and later blue and white sherds of the Ming period on Pulau Sembilan. Settlements appear and disappear over the years as economic, ecological, and other circumstances change. The deserted kampong site on Pulau Mesjid, now virtually inaccessible on account of deep mud and impenetrable undergrowth, was probably finally abandoned as a result of the growth of the nearby oil port of Pangkalan Susu, which has much more to offer in the way of amenities.

Although we did not find any blue and white sherds at Pulau Kompei, it is unlikely that such an attractive anchorage was in complete disuse for any length of time. The presence of a number of fifteenth or sixteenth century I slamic nisan [grave markers] and a local shrine known as keramat panjang near the headland may indicate that settlements still existed at that period. This can be confirmed only by actual excavation along the beach itself, at or above the tide mark where earlier settlements are most likely to have been located.

Beads. A total of 2,465 beads of various shapes and sizes were recovered as surface finds at Pulau Kompei. ${ }^{39}$ Most of them came from a limited area immediately in front of the village school, where, according to the penghulu, Pak Abdul Manaf, children have been collecting beads for many years. The high concentration of beads would suggest that a trade in them was once carried on in this area.

Gemstones. A total of nine small gemstones were found in roughly the same area as the main concentration of beads. They include seven stones known locally as batu delima, which have been identified as almandine pyrope, one tourmaline, and a type of sapphire. ${ }^{40}$ It is of course impossible to judge when these stones may have been lost.

Glass. One small fragment of thin, pale green glass containing minute bubbles was found in association with Sung period sherd material. It is similar to fragments of glass excavated from a twelfth-fourteenth century occupation level at Kota Cina and may be of Middle Eastern or Indian origin.

Bricks and Stone. Fragments of bricks similar to the ones used to build three religious structures at Kota Cina were found near the center of the village, between the headland and the graveyard at the northern end of the settlement. These bricks are distinguishable from modern bricks by their wafer-like appearance and their greater breadth.

Two granite lintels are incorporated into the "keramat panjang" (see above). In addition to these, two fragments of a friable, pinkish quartz, again similar to stone recovered at Kota Cina, were found in the area of the school field (Plate 3).

39. Thirty-three are carnelian and eleven garnets. The remainder, a total of 2,421 , are of monochrome glass of various colors, including an opaque reddish variety known as mutisalah. An analysis is given in Appendix 2. Lamb notes that mutisalah beads occur in large numbers in South Indian settlement sites and that there is not one region in Southeast Asia which has failed to produce beads of this type. See Alastair Lamb, "Some Observations on Stone and Glass Beads in Early South-east Asia," JMBRAS, 38, 2 (1965), pp. 87-124.

40. The authors are indebted to Dr. Stephen Pierce, formerly with the Union Oil Co., Medan for the identification of these stones. Five of the batu delima are no more than three to four millimeters in diameter. The other two are up to ten millimeters in length and both have a small hole for suspension drilled through one end. They have been polished and are rather irregular in shape. 
One fragment is chamfered as though it was once part of a carved pedestal or other object.

The presence of early building materials, such as brick and granite, suggests that there may have been a permanent religious structure at Pulau Kompei during the eleventh or early twelfth centuries, similar to those found at Kota Cina. The presence of bricks in the village away from the beach may also indicate that at least one such structure was built inland from the water's edge.

Coins. All but one of the thirty-six coins recovered from various parts of the village are Chinese (see Appendix 3). Five date from the $T$ 'ang period and twentyseven from the northern Sung. Three are unidentifiable due to advanced corrosion, and one was a copper one-cent piece of the Nederlands Indië, dated 1907.

\section{The Location of Historical Kompei}

When Chau Ju-kua mentioned the name Kien-pi (監篦), he described it as "lying right at the mouth of the road" (當路口), 41 a description which admirably suits the anchorage at Pulau Kompei. Kien-pi was "much resorted to by trading ships as an anchorage." ${ }^{42}$ He went on to relate its location to that of other Sumatran polities, saying that "it can be reached from the San-fo-tsi country . . . in half a month's sailing," 43 and that "Five days' journey by water brings one to the kingdom of Lan-wu-li." 44 These comments confirm the position of the anchorage relative to San-fo-tsi, but more exactly to Lan-wu-li or Lambri at the northern tip of Aceh, only five days' sailing to the northwest. The distance to San-fo-tsi and the south of Sumatra is more or less three times that to the north. Chau's statement may be taken to confirm the relative sailing distances between Jambi, Kompei, and Lambri. Lambri's location is generally agreed to be at the northern tip of Aceh, somewhere in the vicinity of the modern provincial capital of Kutaraja in Aceh Besar. ${ }^{45}$

Hirth and Rockhill, discussing Chau Ju-kua's work, identified Kompei (Kampei or Kampe) with "the modern Kampar on the east coast of Sumatra", stating that "the identification with Kampar does not admit of doubt." 46 But, provided that Chau Ju-kua's information regarding sailing times is correct, the distances involved in fact eliminate the Kampar area as being the location of Kompei. Hirth and Rockhill do observe that "the indications furnished by our author [Chua Jukua] would lead us to extend 'Kien-pi' to near the northwest extremity of Sumatra." 47

41. Hirth and Rockhill, Chau, p. 71. (當路口).

42. Ibid., p. 71 .

43. Ibid.

44. Ibid.

45. Wolters, Fall, p. 43.

46. Hirth and Rockhill, Chau, p. 72. In the seventeenth century, traders avoided the mouth of the Kampar because its tidal currents and shifting channel made navigation difficult. A similar situation may have existed in earlier times. See Christine Dobbin, "Economic Change in Minangkabau as a Factor in the Rise of the Padri Movement, 1784-1830," Indonesia, 23 (April 1977), pp, 1-38, especially p. $8 \mathrm{n} .32$.

47. Hirth and Rockhill, Chau, p. 72 . 
Archaeological evidence from the Pulau Kompei site confirms an early first millennium date for Pulau Kompei in northeast Sumatra. The Chinese coins date from no later than the twelfth century, and the ceramic evidence is also in line with this twelfth century date. This suggests that the anchorage was frequented by merchant shipping during the century before Chau Ju-kua committed his information to writing.

Gerini, who refers to "Chien-pi or Kam-pi, Kam-pei," notes that in the thirteenth century, Kampei was "a revolving colony of San-fo-chi, with a warlike population, probably Malays, carrying on a trade in tin, ivory and pearls." He states that it is :

Not likely to be Kampar, the name of which is spelled $甘 \uplus, \mathrm{Kan}-\mathrm{pa}$, in the Chinese map published by Phillips, nor Jempa or Jumpa in Pasangan, North Sumatra. There is a Kampi promontory at the northern part of the entrance to the Banju Asin, and a Kumpai island at the northeast end of Aru Bay, either of which may be the place intended. Kumpei is, however, in the Chinese map just alluded to, spelled $甘$ 标, Kan-pei, which fact condemns the latter alternative. From the fact of tin being an article of trade in the country some district on the west coast of the Malay peninsula may be meant (Ghirbi) .

He further notes that "every year ships go from San-fo-chi, Chi-to (Ka-to, Telok Kruit in west Sumatra?) and Chien-pi (Kampi, Ghirbi?) to Nan-p'i (Malabar)," information which he has presumably taken from Chau Ju-kua. ${ }^{48}$

Schlegel translates the name as Kien pi (監篦) and notes that these characters "are pronounced in Amoy as Kam-pi, and in Canton as Kam-pei." He states that:

they may represent either the island Kampei (also called Sampa tuwah), on the east coast of Sumatra in the strait of Malacca, near the coast of Langkat, or, what is more likely, Muara Kompeh (the bay of Kompeh), a village situated in the state of Djambi, at the confluence of the rivers Kompeh and Djambi. It is the principal sea port of the country. . . . ${ }^{49}$

Mills, in his comments on the Wu-pei Chih charts, gives the following fifteenth century southern sailing route along the northeast coast of Sumatra:

$\begin{array}{lll}\text { 急水櫒 } & \text { Chui sui wan } & \text { Strong current bay (Telok Sumawe). } \\ \text { 巴砩磌 } & \text { Pa lu t'ou } & \text { Perlak Head or Diamond Point. } \\ \text { 甘标港 } & \text { Kan pei chiang } & \text { Kanpei River. } \\ \text { 亞路 } & \text { Ya'lu } & \text { Aru = Deli. } \\ \text { 單嶼 } & \text { Tan hsu } & \text { Single Island, Pualu Berhala. }{ }^{50}\end{array}$

48. George E. Gerini, Research on Ptolemy's Geography of Eastern Asia (London: Royal Asiatic Society, 1909), p. 628.

49. Schlegel, Old States, p. 34. Pelliot, writing in 1904, noted that Schlegel reestablished correctly the Chinese characters 監篦 as Kien-pi (Kompei). Paul Pelliot, "Deux itinérères de Chine en Inde à la fin du VIIIe siècle," Bulletin de l'École d'Extrême Orient, 4 (1904), p. 344.

50. Mills, "Malaya," p. 11. 
The route clearly indicates a position for Kampei between Diamond Point (Tanjong Jambuair) in Aceh and the Kuala Belawan, or Deli river, area.

Writing in the early nineteenth century, Anderson, quoting Lt. Rose's Sailing Directions for the east coast of Sumatra, described the seaward approach to Pulau Kompei and Aru Bay as follows:

From Timian [Tamiang] to Kwala Bubon [the entrance to the Sungei Langkat] the land forms a deep bay, not easily perceived from a distance, in consequence of two islands that front it, and which are not easily distinguished from the mainland, unless when close in shore. The names of the islands are Pulo Tampasalee and Pulo Sampatuah (Pulo Tampalis and Pulo Kampei). Between these islands, the Malays informed us that there was a safe channel that leads into a river called the Sungy Kayu Lapan.

Anderson, then, appears to have mistaken the position of Pulau Sembilan (Pulo Tampalis) which lies to the south of Kompei, although he accurately positioned the Sungei Besitang which flows into Aru Bay:

Sungy Besitang is a small river. . . There is a small village, with about ten houses, and one hundred inhabitants. It was formerly a very prosperous place and is now under the authority of Langkat. There used to be a great quantity of paddy exported, but now very little. The chief produce is dammar, rattans, wax and ivory. . . ${ }^{51}$

Van Rijn van Alkemade, writing in 1889, gave a more complete description of the southern, seaward, approach to Pulau Kompei:

Not far past the mouth of the Babalan river, we passed the southern entrance to Aru Bay, a fairly deepwater channel between the Sumatra coast and Pulau Sembilan which is almost part of the Sumatra East Coast, due to the presence of a sandbank. This is always the case in this region and it is difficult for larger ships to enter. We reached the northern entrance to the bay after about four and a half hours' steaming from Tanjong Pura; the channel is well marked, and, as here there is always eight to ten feet of water, we had less trouble from pitching and tossing than during the departure from the Langkat river. Between the islands of Kampei and Sembilan, we steamed by less troubled waters into Aru Bay.

Pulau Kampei as seen from the sea presented a pleasant view. The sparkling white beach rises gently to higher terrain covered with light green grass, behind which, in the distance, the fortified house of Datu Bintara and the native overseers of the law came into view. The whole scene made an impression of seeing before one a fortification complete with breastwork. If, however, one steams around the corner of Pulau Kampei, the impression soon changes to a wholly different one, and one sees that the actual kampong consists of some decaying attap houses, some of which are built on piles on the beach. ${ }^{52}$

He went on to comment on the geography of the island, noting that:

The shape of the island is approximately that of a semi-circle, the diameter of which lies from north to south and forms the eastern or seaward side and has a length of about nine kilometers. One may accept that this island has not come into existence due to alluvial deposition, owing to the presence of

51. Anderson, Mission, p. 239.

52. Van Alkemade, "Bezoek," p. 57. 
a rather deep channel between the mainland and the neighboring Pulau Sembilan, whilst the formation of the island is of a much older date than the mainland shore. Hills of perhaps one hundred and fifty to five hundred feet, separated by equally deep valleys and joined by plateaux, rise up so that the strand vegetation is very quickly replaced by dry land species. ${ }^{53}$

In 1916 Lekkerkerker noted that "Pulau Sembilan and Pulau Kompei on the opposite side of the deep Aru Bay are high and dry, and are [among] the few hilly areas on the East Coast [of Sumatra]." 54

\section{Natural Resources and Suggested Locations of "Kompei"}

Some confusion has arisen concerning the location of Kompei as a result of references in the earlier Chinese reports to the products of the country, and the apparent incompatibility of these with the location of the toponym as implied in the sailing directions. The first Chinese reference to a place named "Kompei" was, as we have noted, in $\mathrm{AD} 662$, and the last which we have cited was in $\mathrm{AD} 1433$. The locational references by Chau Ju-kua in the twelfth century clearly indicate a polity situated on the northeast coast of Sumatra. The earliest reference in the seventh century Hsin T'ang Shu is, however, less certain.

In the case of an entrepot of some magnitude, such as San-fo-chi, which could draw on products from over a wide area and subsequently re-export them, problems of identification of the actual source of a product are complex. Indeed, it was not unusual for the Chinese mistakenly to identify the products of a wide area with a single port or entrepot. Often the Chinese officials responsible for compiling the records would have no first-hand knowledge of the areas about which they were writing. They were removed both in time and distance from those with firsthand experience of the areas in question. ${ }^{55}$

With this reservation in mind, we can turn to the problems, raised by Chau Ju-kua's text, concerning the relation between the location of Kompei and the products reportedly exported at that time. The Chu-fan-chi states that Kompei "produces tin, elephants' tusks and pearls," ${ }^{56}$ and that "every year ships come to this country (Ku-lin = Quilon) from San-fo-chi, Kien-pi and Ki-t'o, and the articles they trade with are the same as in Nan-p'i (Malabar)." 57 Hirth and Rockhill add a note to the effect that:

The Ling-wai-tai-ta, 2,13 says: "Every year Kien-pi takes elephants and cattle, and the Arabs take horses to trade in this country (of Ku-lin)". This passage appears to be the basis for Chau Ju-kua's remarks, he has only added the names of San-fo-ts'i and Ki-t'o, presumably because they were adjacent to Kien-pi and in Sumatra. It seems just possible that Ki-t'o may be the same as the pilgrim I-tsing's Kie-ch'a (羯茶), which was on the extreme N.E. coast of Sumatra, and the last port-of-call (at least in

53. Ibid., p. 58 .

54. Cornelis Lekkerkerker, Land en Volk van Sumatra (Leiden: Brill, 1916), p. 302 .

55. See Paul Wheatley, The Golden Khersonese (Kuala Lumpur: University of Malaya Press, 1961), pp. 1-3.

56. Hirth and Rockhill, Chau, p. 71.

57. Ibid., p. 89. 
the seventh century, but very probably also in later days) for ships going from San-fo-ts'i to India. ${ }^{58}$

I-tsing's Kie-ch'a or Chieh-ch'a was, however, Kedah on the Malay peninsula, no more than a day's sail to the northeast of Kompei. Kedah was the focus for Arab shipping crossing the Indian ocean from early times. ${ }^{59}$

Writing nearly six hundred years later about Pulau Kompei in Aru Bay, Anderson listed "paddy, dammar, rattan, wax and ivory" as articles of trade. ${ }^{60}$ He suggested that the numerous small harbors along this stretch of coast developed as a response to the commercial acumen of the hill peoples, the Batak, Alas, and Gayo, who in the late eighteenth and early nineteenth centuries brought down gold and such forest products as dammar, wax, but also camphor, to be exchanged for salt, cloth, iron, and numerous other items. ${ }^{61}$ Among the Karo Batak, such traders were known as pelanja sira (salt carriers), a name which signifies their all-important function as suppliers of salt to the highland populations. ${ }^{62}$

The only article common to the reports of the twelfth and nineteenth century is ivory. This, in fact, appears in numerous notices regarding Sumatra, leading to the conclusion that elephant hunting must have been fairly common throughout the island. In connection with the earlier reference to pearls, it is interesting to note that in the 1920 s pearl fishing was still being carried out near Pulau Sembilan, adjacent to Pulau Kompei. ${ }^{63}$

The early reference to tin in the Aru Bay area, however, does pose a problem. Tin is not to be found here, at least not in commercial quantity, although one mention of tin in the region appears in an eighteenth century report, where it is noted that:

Langkatt, a small port in S umatra unknown to Europeans . . . produces

Pepper, Tin, Rice and a Pale Gold favorably situated for an inland trade. ${ }^{64}$

"Langkatt" was probably a point on the Wampu or Langkat river some distance to the south and is undisputably in the same general area as Pulau Kompei. Lacking geological evidence for tin production in the area, it seems possible that the tin from Langkatt may have been a re-export. ${ }^{65}$

Hirth and Rockhill realized that "the existence of tin in Kien-pi points to the East part of the island [of Sumatra]." They quote Crawfurd's statement that the

58. Ibid., p. $91, \mathrm{n} .16$.

59. See G. R. Tibbetts, "The Malay Peninsula as known to the Arab Geographers," Malayan Journal of Tropical Geography, 9 (1956), pp. 21-60.

60. Anderson, Mission, p. 237.

61. John Anderson, Acheen (1840; reprint ed. Kuala Lumpur: Oxford in Asia, 1971). See especially Chapter 13, in which ports, products, and people of Sumatra are discussed.

62. We are grateful to Drs. Terbit Sembiring for discussing this matter.

63. Heyting, "Memorie."

64. Captain Leight, "A Brief Account of the Several Countries Surrounding Prince of Wales's Island with Their Production," JMBRAS, 16, 1 (1938), pp. 123-26.

65. See below. Some of the older inhabitants of Pulau Kompei speak of close and regular connections with Pulau Pinang and Kedah in the years before the end of colonial rule. Tin ore could have been brought across from the Malay peninsula. 
geographical distribution of tin is confined to the island of Bangka and the Malay Peninsula, including Junk Ceylon and other west coast islets. ${ }^{66}$ Van Bemmelen, with far greater geological knowledge at his disposal than earlier scholars, gives the main (commercial) sources of tin in the Sumatra region as Bangka, Billiton, and Singkep, with other lesser sources in Rokan, Siak, the lower course of the Kampar river, and the neighborhood of Bangkinang and Balung on the upper part of the Kampar kiri. He refers to other small deposits existing at various places in the Riau-Lingga archipelago. ${ }^{67}$ It is perhaps significant that no tin appears north of the Rokan on mainland Sumatra.

The existence of a major trade in tin is therefore incompatible with what we know of the geology of the immediate hinterland of the Aru Bay area. This situation, as Hirth and Rockhill have indicated, points away from the northeast coast to an area on the east coast south of Rokan. The only possible alternative explanation would be that tin was re-exported from Kompei.

Although, as noted above, pearl fishing was being carried on near Pulau Kompei some sixty years ago, similar comments would appear to hold good for any major trade in pearls. Gem quality pearls are obtained from the Pinctada species of mollusc, and more especially from $P$. vulgaris (Sch.). They may be obtained also from $P$. margitifera (Linn.), but on a lesser scale. ${ }^{68}$ Wheatley cites the coast of Kampar as a Sumatran source and notes that Srivijaya was the main Southeast Asian collecting center for pearls. ${ }^{69}$ The emphasis is yet again on the southeastern coast rather than the northeastern part of Sumatra. In the search for a second locality of the same, or at least similar, name as Kompei, Gerini's comment rejecting northeastern Sumatra (though not necessarily his tentative suggestion of the west coast of peninsular Malaysia) may also be pertinent.

Was there a mistake in Chau Ju-kua's text regarding two toponyms called Kompei (or Kompeh)? It is possible, though there is no doubt from the sailing directions that Pulau Kompei in Aru Bay is intended. There may, however, have been a second harbor, also named Kompeh, which was the source of tin (and pearls?). If this supposition is correct, Schlegel's second alternative for the location of Kompei, Muara Kompeh, on the lower course of the Batang Hari river presents itself as a possible candidate. Although no archaeological remains have been reported from Muara Kompeh, Adam, who carried out a survey on the lower Batang Hari in 1920 , recorded that there was a tradition that linked it with pre-Islamic "Hindu" settlement. ${ }^{70}$ This may suggest that it was once of considerable importance. Situated at the confluence of the Kompeh and Batang Hari rivers, Muara Kompeh was later the major port for the Jambi area, ${ }^{71}$ functioning as a trading outlet for a

66. Hirth and Rockhill, Chau, p. 72.

67. R. W. van Bemmelen, The Geology of Indonesia, 2 (The Hague: Nijhoff, 1970), pp. 193-94.

68. On pearls, see Burkhill, Economic Products, pp. 1760-65.

69. Paul Wheatley, "Geographical Notes on Some Commodities Involved in Sung Maritime Trade," JMBRAS, 32, 2 (1961), p. 90.

70. T. Adam, "Oudheden te Djambi 1," OV (1921), App. U, pp. 194-97.

71. On Muara Kompeh, see Encyclopaedie van Nederlands Indië, 4 vols. (The Hague: Nijhoff, 1917-21), 2, p. 762. Also: Jambi (Djambi), 1, p. 608. Schnitger, who carried out the first excavations at Muara Jambi in 1936 realized that the site was of major importance but never followed up his initial investigations. Friederich $M$. 
hinterland which extends deep into the Bukit Barisan mountain range. Moreover, it is only a short distance downstream from the major "Srivijayan" site of Muara Jambi and would have been ideally situated to carry on trading activities relating to the royal residential and ritual centers further upriver. As a port, Muara Kompeh would have been remembered by traders, even though the seat of power may have lain further upstream at Muara Jambi.

\section{Conclusion}

No references to Kompei's antiquities appeared during the colonial period. Nineteenth century antiquaries based their expectations almost exclusively on grandiose monumental remains, and the few ancient bricks on the sand at Pulau Kompei are unlikely to have attracted much attention.

Obviously much more basic research is required before a more complete picture will appear of Kompei's place in the social and commercial context of northeast Sumatran history of the late first and early second millennium. The evidence from both historical sources and from the site of Pulau Kompei itself leads us to believe that present-day Pulau Kompei is synonymous with that of the ancient anchorage Kien-pi mentioned in the Chinese records of the thirteenth and fifteenth centuries, thus confirming the interpretation of Pelliot, Mills, and Wolters.

Kompei appears as a regular port of call for ships sailing along the east coast of Sumatra between south India on the one hand and "Srivijaya" Jambi, Java, and China on the other. The site may also have had links with contemporary sites on the west coast of the Malay peninsula (Kedah), barely a day's sail to the northeast. Its geographical relationship with Tamiang and Lambri to the north and to Kota Cina on the Sungei Deli estuary to the south suggests that it was but one among a number of small but nevertheless important anchorages along this part of the Sumatran coast, centers which were important in the context of both local and international trade.

Although Kompei was reportedly a source of ivory and pearls, its major attraction appears to have been as a safe anchorage. The hinterland of Aru Bay may contain undisclosed mineral resources such as deposits of alluvial gold, and it is possible that natural petroleum products such as earth oil and pitch were also available here. Even so, much of the area's commerce may have been of a secondary nature through more important ports such as Kota Cina to the south, or through Tamiang or even Samudera Pasai to the north, all of which would have offered more direct advantages to international traders.

The apparent absence of green glazed Lung ch'üan (celadon) porcelain and the fact that the name Kompei does not appear in the Yuan shih suggests that its importance as a port of call had already waned by the mid-thirteenth century. This may have been occasioned by the rise of a new overlord at Tamiang to the north, or by the development of an alternative harbor at Kota Cina some seventy kilometers to the south. Kota Cina, in particular, appears to have had more direct and better access to the valuable forest products of the mountainous interior. It

Schnitger, The Archaeology of Hindoo Sumatra (Leiden: Brill, 1937). The extent and importance of the Muara Jambi site has only recently come to light following the initiation of a rehabilitation program by the Indonesian Research Center of Archaeology. A full report is to be published but a brief discussion is available; see Mohammad Nazir, Mengenal Candi-candi Muara Jambi (Jambi: Departemen P. dan K., n.d.). 
was strategically situated to exploit transinsular portages to the benzoin- and camphor-producing areas of the Bukit Barisan, west and north of Lake Toba. Kota Cina may also have benefited from having gold and a larger population in its immediate hinterland. By the fifteenth century Kota Cina had, however, disappeared and Kompei emerged again as an attractive anchorage.

The focus of habitation may also have shifted inland away from the beach at Pulau Kompei, a trend which seems to have been under way in this region by the fourteenth century.

Further research at Pulau Kompei and other sites around the Aru Bay area should fill in some of the many gaps in our present knowledge. Further information, for instance, is needed about Kota Batu and other sites said to exist in the hinterland and how these relate to the region's history. This kind of information will also complement work being undertaken in the Deli area. 


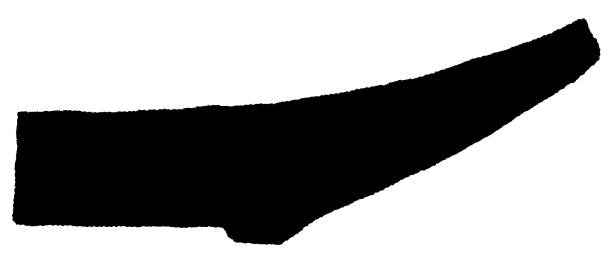

A
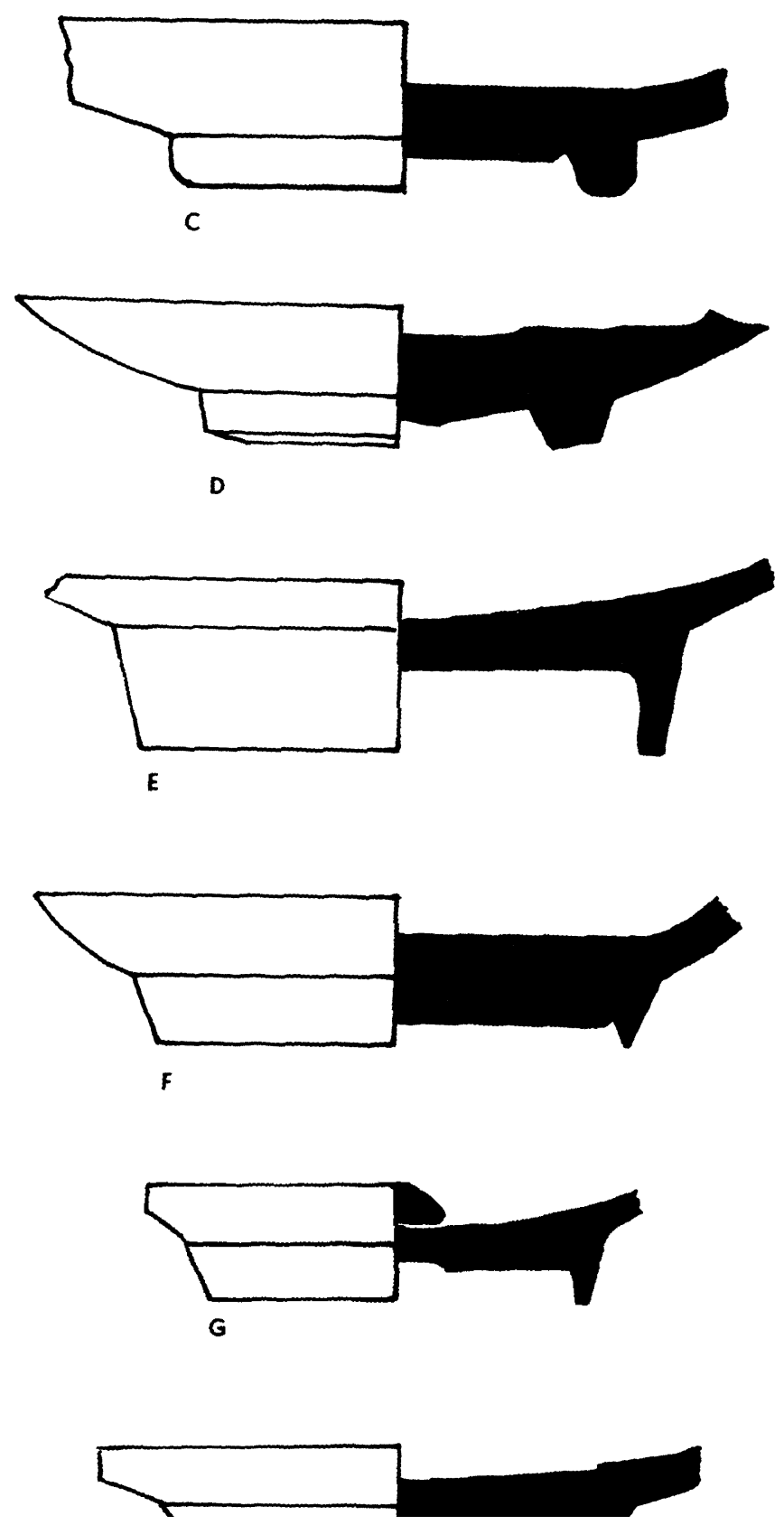
Appendix 1

Ceramics: Chinese Stoneware Sherds Recovered at Pulau Kompei

Fig. 1 A. Green glazed stoneware bowl: undecorated base sherd with finely crackled glaze, low footrim, interior of base unglazed. Maximum Extant Dimension (MED) $90 \mathrm{~mm}$.

B. Clear glazed stoneware bowl: undecorated base sherd with clear, shiny crackled glaze over a white slip? MED $74 \mathrm{~mm}$. Footrim square cut.

C. White glazed stoneware bowl: undecorated base sherd with clear, shiny glaze. Diameter footrim $52 \mathrm{~mm}$. Interior of base unglazed, slight "ring" incised around the interior of the foot.

D. White glazed stoneware bowl: base sherd with shiny, opaque crackled glaze, undecorated except for a recessed ring carved into the center of the cavetto. Diameter footrim $47 \mathrm{~mm}$. Interior of base unglazed, footrim and interior of base carved to angular finish.

E. Grayish yellow glazed stoneware bowl: undecorated base sherd with opaque glaze (weathered). Diameter footrim $68 \mathrm{~mm}$. Interior of base unglazed, high carved footrim.

F. Ch'ing pai glazed porcelaneous stoneware bowl: undecorated base sherd with shiny, crackled glaze. Diameter footrim $56 \mathrm{~mm}$. Interior of base unglazed, recessed, with a slight ring incised around the interior of the tapered footring.

G. Ch'ing pai glazed porcelaneous stoneware bowl: base sherd with appliqué tortoise in center and lines radiating starlike from center to outer rim, shiny crackled glaze. Diameter footrim $45 \mathrm{~mm}$. Interior of base unglazed, slightly recessed area in center of the base.

H. Ch'ing pai glazed porcelaneous stoneware bowl: base sherd with slightly recessed interior and shiny, crackled glaze. Diameter footrim $48 \mathrm{~mm}$. Interior of base unglazed and slightly recessed with a ring incised around the interior of the rounded footring. 


$$
\bar{z}
$$


Fig. 2 A. Ch'ing pai glazed porcelaneous stoneware bowl: base sherd with slightly recessed interior (as in Fig. $1 \mathrm{H}$ ), opaque glaze. Base flat and unglazed with a finely cut ring to mark the interior edge of the footring. Diameter footrim $50 \mathrm{~mm}$.

B. Grayish yellow glazed porcelaneous stoneware bowl: undecorated base sherd with opaque, shiny (mutton fat) glaze. Diameter footrim $58 \mathrm{~mm}$. Interior of base unglazed; rounded, slightly tapered footrim.

C. Ch'ing pai glazed porcelaneous stoneware bowl: base sherd with appliqué tortoise in center and lines radiating starlike to the rim, clear, shiny glaze with large crackle. Diameter footrim $39 \mathrm{~mm}$. Flat interior of base unglazed, slightly tapered carved foot. From Paluh Tabuhan, Aru Bay (compare with Fig. $1 \mathrm{G}$ above).

D. Green glazed stoneware bowl: undecorated, with weathered, crackled glaze. Everted, flaring mouth and high footring. Recovered from the sea at Pulau Kompei (see Plate 2). 
Appendix 2

Beads Recovered at Pulau Kompei

Semi-precious stone beads:

Carnelian

Garnet

Glass beads: monochrome, simple seed beads:

Mutisalah, seed beads seed beads

$<4 \mathrm{~mm}$

disc beads

$>4 \mathrm{~mm}$

Yellow, opaque seed beads

$<4 \mathrm{~mm}$

disc

Amber-yellow, opaque seed beads

$<4 \mathrm{~mm}$

$\underline{96}$

Black, opaque seed beads

$<4 \mathrm{~mm}$

912

disc

$>4 \mathrm{~mm}$

50

$\underline{5}$

Blue-green seed beads

$<4 \mathrm{~mm}$

221

$>4 \mathrm{~mm}$

9

White, opaque seed beads

$<4 \mathrm{~mm}$

17

$>4 \mathrm{~mm}$

3

Purple, seed beads

$<4 \mathrm{~mm}$

2

Glass beads: feature specimens:

Yellow, opaque bicone

Yellow, opaque bicone

Yellow, clear

White, opaque, spherical

Blue, tapered cylinder

Blue, dimpled

Blue, cruciform

Black, banded/white

Length $13 \mathrm{~mm}$

Length $8 \mathrm{~mm}$

Length $6 \mathrm{~mm}$

Length $7 \mathrm{~mm}$

Length $10 \mathrm{~mm}$

Length $5 \mathrm{~mm}$

Length $6 \mathrm{~mm}$

Length $7 \mathrm{~mm}$ 
Appendix 3

Coins Recovered at Pulau Kompei ${ }^{72}$

Chinese

T'ang (618-907 AD)

Sung (960-1127: Pei Sung)

$T^{\prime}$ ai Tsung (967-997)

Chen Tsung (998-1002)

Jen Tsung (1023-1063)

Ying Tsung (1064-1067)

Shen Tsung (1068-1085)

Che Tsung (1086-1100)

Hui Tsung (1101-1125)

Unidentifiable

Total
Legend

K'ai Yuan Tung-pao

Chih Tao Yuan-pao (995-997) 1

Ching Te Yuan-pao (1004-1008) 1

Huang Sung Tung-pao (1034-1038) 1

Ching Li Chung-pao (1041-1049) 1

Chih Ho Yuan-pao (1054-1056) 1

Chia Yu Yuan-pao (1056-1064) 1

Chih Ping Yuan-pao (1064-1067) 1

Hsi Ning Yuan-pao (1068-1078) 3

Yuan Feng Tung-pao (1078-1085) 11*

Yuan Yu Tung-pao (1086-1094) 3

Ta Kuan Tung-pao (1107-1111) 1

Hsuan Ho Tung-pao (1119-1126) _ 2

1

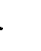
1

1

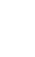

3

3

Number

5

* Includes 1 Value two coin.

72. Identification of the coins has been made on the basis of illustrations in Friederich Schjoth, Chinese Currency, revised and edited by Virgil Hancock (Iola, Wis: Krause, 1965). 